Our Nature (2012) 10: 249-257

\title{
Seasonal Variations in Physico-Chemical Characterstics of Tapi Estuary in Hazira Industrial Area
}

\author{
M. Gadhia, R. Surana and E. Ansari \\ Department of Aquatic Biology \\ Veer Narmad South Gujarat University, Surat \\ Email: ranjanasurana27@yahoo.com,mohinigadhia@yahoo.co.in
}

\begin{abstract}
Present study was carried out to determine the important physico chemical parameters of water of Tapi estuary in Hazira industrial area. Tapi estuary receives the inputs of organic matter and nutrients coming from the domestic wastewater discharges from Surat City, a textile hub as well as industrial effluents from Hazira, a major industrial Complex of Gujarat, India. Uncontrolled discharges of domestic wastes and industrial effluents have affected the estuary. Present study was carried out from June 2011 to May 2012 to study the impacts of uncontrolled discharges on physicochemical characteristics of water. Samples were collected monthly in the morning during low tide to determine the important physico chemical parameters Viz. Turbidity, conductivity, total solid, total dissolved solid, salinity, $\mathrm{pH}$, dissolved oxygen, BOD, COD, Calcium, chloride, sodium , potassium and nutrients like nitrate, nitrite and phosphate. Dissolved oxygen was found extremely low during the study period. High biochemical oxygen demand (BOD) and Chemical Oxygen demand (COD) showed that the water quality of estuary has been affected by industrial and domestic effluents.
\end{abstract}

Key words: Physicochemical characteristics, Water, Nutrients, Hazira, Tapi estuary

\section{Introduction}

Estuarine and coastal areas are complex and dynamic aquatic environment (Morris, et al.1995). Estuaries are economically important ecosystems for fisheries in tropical regions (Kawabata et al., 1993) and they act as a transitional zone between land and sea (Bardarudeen et al., 1996). When river water mixes with seawater, a large number of physical and chemical processes take place and may influence water quality. The quality of surface water is very sensitive issue. The natural processes, such as precipitation inputs, erosion, weathering of crustal materials, as well as the anthropogenic activities calling for increasing exploitation of water resources, together determine the quality of surface water in a region. Rivers play a major role in assimilation or carrying of municipal and Industrial wastewater and runoff from agricultural land, the former constitutes the constant polluting source whereas the later is a seasonal phenomenon. Many reports are available on the physico-chemical features of Indian estuaries (Govindasamy et al., 2000; Rajasegar, 2003; Balasubramanian and Kannan, 2005; Paramasivam and Kannan, 2005; Rajaram et al., 2005; Ajithkumar et al., 2006; Asha and Diwakar, 2007; Ashok Prabu et al., 2008; Saravanakumar et al., 
2008; Gowda et al., 2009; Vengadesh et al., 2009). Hazira is located on the bank of the Tapi River, eight kilometers from the Arabian Sea. It is a home to major industrial and shipping facilities like Essar Group of Industries, Kribhco, Shell, Larsen andToubro, NTPC, ONGC,GAIL, GSPC,

UltraTech, Reliance and many more. To trace the influence of these activities, seasonal variations in important physico chemical parameters of water of Tapi estuary near Mora village in Hazira industrial area was studied from June 2011 to May 2012.

\section{Materials and Methods}

Water samples were collected every month in the morning during low tide from June 2011 to May 2012 from Tapi estuary near Mora village in Hazira industrial area (Fig. $1)$.

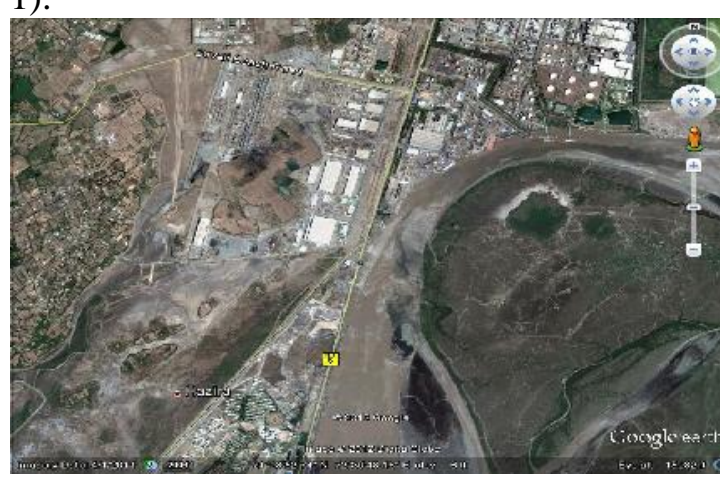

Figure 1. Study area

Surface water samples were collected with a clean plastic bucket. Preservation and analysis of the water samples were done as per standard methods. The water samples were analyzed for turbidity, conductivity, total solid, total dissolved solid, salinity, $\mathrm{pH}$, dissolved oxygen, BOD, COD, Calcium, chloride, sodium, potassium and nutrients like nitrate, nitrite and phosphate. Standard procedures recommended by the (APHA, 1998) and Trivedy and Goel (1984) were followed during the sample collection, handling, preservation and analysis to ensure data quality and consistency.

\section{Results and discussion}

The mean of analytical results of physicochemical aspects of water samples were summarized in Fig. 2-8. Surface water temperature varied from $20^{\circ} \mathrm{C}$ to $33{ }^{\circ} \mathrm{C}$. Generally, surface water temperature is influenced by the intensity of solar radiation, evaporation, freshwater influx and cooling and mix up with ebb and flow from adjoining neritic waters. The highest $(29 \pm 1.857)$ and lowest $(27 \pm 1.6431)$ values were observed during pre-monsoon and post monsoon seasons, respectively (Fig. 2). Higher temperature values recorded in the dry season may be because of heat raising temperature of surface water. Low temperature in post monsoon season was due to winter (Das et al., 1997; Karuppasamy and Perumal, 2000; Senthilkumar et al., 2002; Santhanam and Perumal, 2003).

Table 1. General coastal cater quality standards (swimming and aquatic life).

\begin{tabular}{|l|l|}
\hline PARAMETERS & STANDARDS \\
\hline $\mathrm{pH}$ & $7.8-8.3$ \\
\hline Temperature (oC) & 30 \\
\hline Turbidity (NTU) & $10 \mathrm{NTU}$ or less \\
\hline Total suspended sediments (TSS) & $25 \mathrm{mg} / \mathrm{l}$ or less \\
\hline Dissolved oxygen (DO) & $4 \mathrm{mg} / \mathrm{l}$ or more \\
\hline Biochemical oxygen demand (BOD) & $30 \mathrm{mg} / \mathrm{l}$ or less \\
\hline Chemical oxygen demand COD & $250 \mathrm{mg} / \mathrm{l}$ or less \\
\hline Nitrate & $10 \mathrm{mg} / \mathrm{l}$ or less \\
\hline Nitrite & $10 \mathrm{mg} / \mathrm{l}$ or less \\
\hline Phosphorus & $40.1 \mathrm{mg} / \mathrm{l}$ or less \\
\hline
\end{tabular}


Turbidity is the material in water that affects the transparency or light scattering of the water. The range for natural water is 1 to 2000 NTU. The measurement unit used to describe turbidity is Nephelometric Turbidity Unit (NTU). Higher value $(152 \pm 48.282 \mathrm{NTU})$ was recorded during pre monsoon and low value during monsoon (54 $\pm 24.052 \mathrm{NTU})$ (Fig. 2). Highest Turbidity in water is caused by the presence of suspended matter such as clay, silts, finely divided organic and inorganic matter, plankton and other microscopic organisms. It has been reported that the wave action increases during pre-monsoon Season resulting in turbulent condition in the coastal waters favoring the resuspension of the bottom sediment due to stirring action that causes low water transparency (Nixon, 1988).

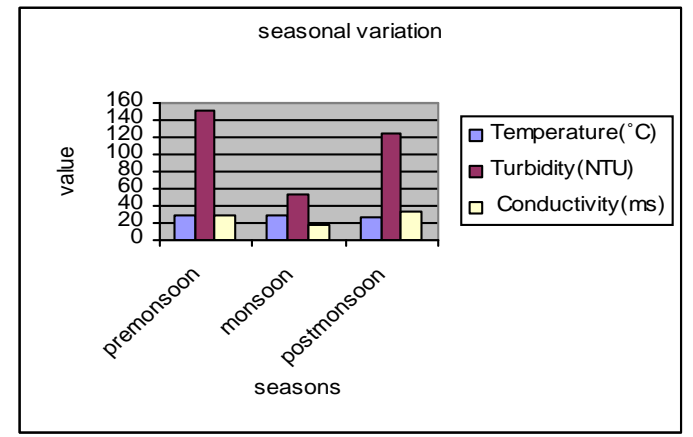

Figure 2. Seasonal variations in Temperature, Turbidity and Conductivity.

The conductivity ranged from 1.5 to 41.306 $\mathrm{mS}$, high during Post monsoon $(32.2695 \pm 4.8420)$ and low in monsoon season 18.4355 \pm 6.5705 ) (Fig. 2). High conductivity during post monsoon might be attributed to low mixing of fresh water input from river. Low value during monsoon season was due to rain and mixing of more fresh water from river. The conductivity values decreased with an increase in rainfall. In the rainy season, the increased volume of water remarkably diluted the water (Izonfuo and Bariweni, 2001).

Total solid value was higher during post monsoon $(37662.5 \pm 5790.94 \mathrm{mg} / \mathrm{l})$ and lower during monsoon season (20795 \pm $5796.0295 \mathrm{mg} / \mathrm{l}$ ) (Fig. 3). TSS is typically composed of fine clay or silt particles, plankton, organic compounds, inorganic compounds or other microorganisms. These suspended particles range size from $10 \mathrm{~nm}$ to $0.1 \mathrm{~nm}$. TSS as well as TDS can be influenced by changes in $\mathrm{pH}$. Changes in the $\mathrm{pH}$ will cause some of the solutes to precipitate or will affect the solubility of the suspended matter. During post monsoon period TSS value was found to be maximum and low during monsoon. TDS value was higher during pre monsoon and lower during monsoon. The mean values for the total dissolved solids (TDS) were higher in dry season than in the rainy season (Fig. 3). The lower values of this parameter suggest that the runoff water only contributes to its dilution in the rainy season (Izonfuo and Bariweni, 2001).

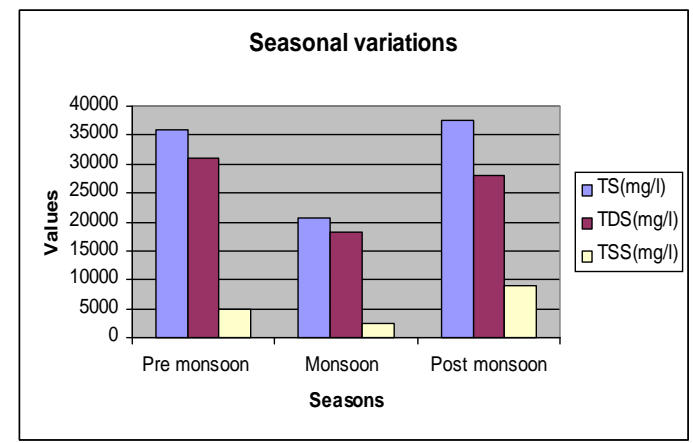

Figure 3. Seasonal variations in TS, TDS and TSS. 
The salinity acts as a limiting factor in the distribution of living organisms, and its variation caused by dilution and evaporation is most likely to influence the fauna in the intertidal zone (Gibson, 1982). Water with a high total dissolved solids indicated more ionic concentration, which is of inferior palatability and can induce an unfavorable physicochemical reaction in the consumers. Kataria et al., (1996) reported that increase in value of TDS indicated pollution by extraneous sources. The high amount of dissolved, suspended and total solids of samples adversely affects the quality of running water and it is unsuitable for any other purpose irrigation and drinking .Generally, changes in the salinity in the estuaries is due to the influx of freshwater from land run off, caused by monsoon or by tidal variations. In the present study, salinity was high during pre monsoon and low during the monsoon season (Fig. 4). Higher

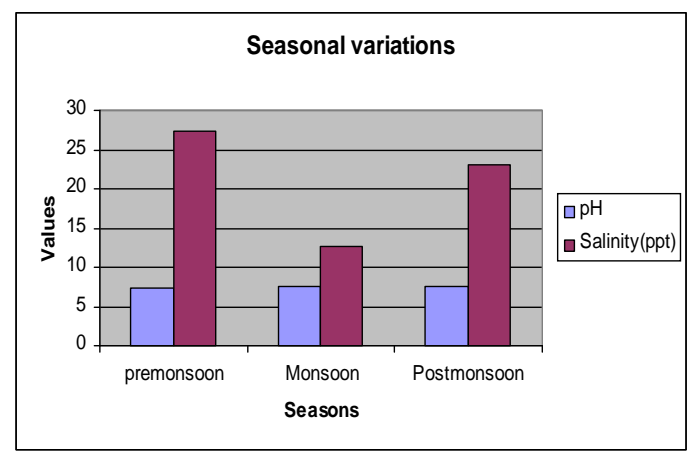

Figure 4. Seasonal variations in $\mathrm{pH}$ and salinity.

values $(27.25 \pm 3.0103 \%$ \% $)$ during pre monsoon could be attributed to the low amount of rainfall (Sampathkumar and Kannan, 1998; Govindasamy et al., 2000; Gowda et al., 2001; Rajasegar, 2003). During the monsoon season (12.65 \pm
$4.0383 \%$ ), the rainfall and the freshwater inflow from the land in turn moderately reduced the salinity as reported by Sai Sastry and Chandramohan (1990) in the Godavari estuary; Mitra et al. (1990) in the Bay of Bengal and coastal waters of Kalpakkam (Satpathy, 1996).

Hydrogen ion concentration $(\mathrm{pH})$ in surface water remained alkaline throughout the study period with no marked difference. Maximum value $(7.65 \pm 0.1258)$ during the end of the monsoon and minimum value (7.4 \pm 0.3109$)$ during pre monsoon was recorded (Fig. 4). Generally, fluctuations in $\mathrm{pH}$ values during different seasons of the year is attributed to factors like removal of $\mathrm{CO}_{2}$ by photosynthesis through bicarbonate degradation, dilution of seawater by freshwater influx, low primary productivity, reduction of salinity and temperature and decomposition of organic materials as stated by Karuppasamy and Perumal, 2000; Rajasegar, 2003.

Variation in dissolved oxygen content was from $2.936 \mathrm{mg} / \mathrm{l}$ to $5.212 \mathrm{mg} / \mathrm{l}$. It is well known that the temperature and salinity affect the dissolution of oxygen (Vijayakumar et al., 2000). In the present investigation, higher values of dissolved oxygen were recorded during monsoon. Higher dissolved oxygen concentration observed during the monsoon season $(5.21 \pm 0.7432)$ might be due to the cumulative effect of higher wind velocity, rainfall and the resultant freshwater mixing (Das et al., 1997). Mitra et al. (1990) mainly attributed seasonal variation of dissolved oxygen to freshwater flow .DO is indicative of the health of an aquatic system, the vital metabolism of aerobic organisms, respiration depends purely on the amount of 
oxygen dissolved in the water. Optimum concentration of dissolved oxygen is essential for maintaining aesthetic qualities water as well as for supporting life. Low value $(2.936 \pm 0.7640)$ was recorded during pre monsoon (Fig. 5).

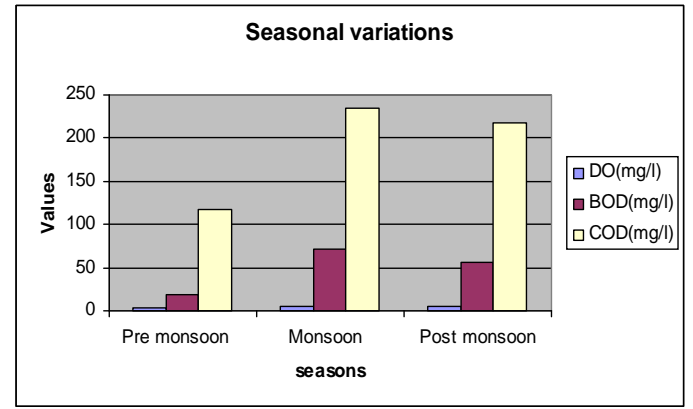

Figure 5. Seasonal variations in DO, BOD and COD.

BOD showed a fluctuation between $19.26 \pm 3.8352 \mathrm{mg} / \mathrm{l}$ to $72 \pm 14.4625$ $\mathrm{mg} /$ respectively during monsoon and pre monsoon seasons (Fig. 5). High BOD might be due to the decomposition of organic matter and decay of vegetation in river which mixed with sea water during rainy season. The value of COD was found maximum (235 $\pm 96.1578 / 1)$ during monsoon season and low value $(118 \pm 31.7280 \mathrm{mg} / \mathrm{l})$ during pre monsoon. (Fig. 5). The monsoon showers brought nutrients from allochthonous sources into the systems elevating the phosphate, nitrate and silicate concentrations in the water. Moderate to high COD values were observed during the post-monsoon when compared to the monsoon season. The high COD load could be due to runoff from the surrounding areas. COD is an indicator of organic pollution, which is caused by the inflow of domestic, livestock and industrial waste that contains elevated levels of organic pollutants (Ayati,
2003). Chemical oxygen demand (COD) and biochemical oxygen demand (BOD,) test results were found comparatively higher in monsoon than pre- monsoon and postmonsoon periods by Joseph and Srivastava (1993) the higher BOD observed during the rainy season implied that high demands for oxygen were made to support life processes. Clark (1986) noted similar situation of higher BOD and concluded that it was due to higher organic waste load experienced in the rainy months. Odokuma and Okpokwasili (1996) also observed that BOD fluctuation between seasons may be attributed to additional organic matter introduced into the river as a result of runoff and soil erosion caused by continuous rain fall in the rainy season.

The chemical oxygen demand (COD) was higher in the rainy season than the dry season. Since COD has a direct relationship with BOD, the reasons adduced for BOD being higher in the rainy season are also responsible for COD. The COD values of the industrial effluents were observed to be high and therefore contributing to the pollution of the river.

Calcium value was found higher $(1409.6 \pm 866.0149 \mathrm{mg} / \mathrm{l})$ during post monsoon and lower value $(315.875 \pm 97.63233$ /l) during monsoon season (Fig. 6).The value of chloride was found higher $(14162 \pm 1530.04875 \mathrm{mg} / \mathrm{l})$ during pre monsoon which might be due to high salinity, tidal flow and low fresh water mixing. Low value was found during monsoon season due to rain and more mixing of fresh water from river. Fluctuation in chloride is not related to pyrite oxidation, but due to the tidal and seasonal changes in the river. Higher value 
of sodium $(\mathrm{mg} / \mathrm{l})$ was found during post monsoon season due to high salinity and low value $(77.7 \mathrm{mg} / \mathrm{l})$ was found during monsoon season due to rain and flow of river water.

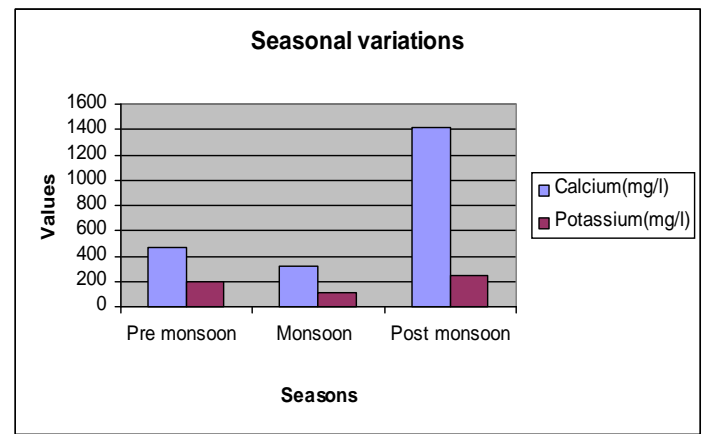

Figure 6. Seasonal variations in Calcium and Potassium.

Freshwater flow constituted the main source of the nutrients in the estuaries. Nitrates value ranged from $2.537 \mathrm{mg} / \mathrm{l}$ to $13.738 \mathrm{mg} / \mathrm{l}$. Mean value $13.7383 \pm 6.502428$ $\mathrm{mg} / \mathrm{l}$ during monsoon season could be mainly due to the organic materials received from the catchments area during the tide (Das et al., 1997). The increased nitrates level was due to fresh water inflow and terrestrial run-off during the monsoon season (Karuppasamy and Perumal, 2000). Another possible way of nitrates entry is through oxidation of ammonia form of nitrogen to nitrite formation (Rajasegar, 2003). The low value $4.411 \pm 0.88749 \mathrm{mg} / \mathrm{l}$ recorded during pre monsoon period may be due to its utilization by phytoplankton as evidenced by high photosynthetic activity and also due to the neritic water dominance, which contained negligible amount of nitrate (Das et al., 1997; Govindasamy et al., 2000). The recorded value of nitrite
$(1.88325 \pm 0.5099 \mathrm{mg} / \mathrm{l})$ could be due to the increased phytoplankton excretion, oxidation of ammonia and reduction of nitrate and by recycling of nitrogen and bacterial decomposition of planktonic detritus present in the environment (Swami et al., 1996; Govindasamy et al., 2000). The recorded low value $(1.1905 \pm 0.4029 \mathrm{mg} / \mathrm{l})$ during pre monsoon seasons may be due to less freshwater inflow and high salinity (Mani and Krishnamurthy, 1989; Murugan and Ayyakkannu, 1991).

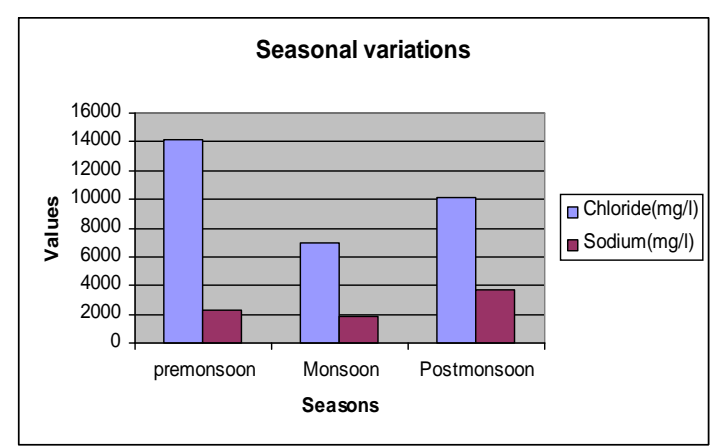

Figure 7. Seasonal variations in Chloride and Sodium

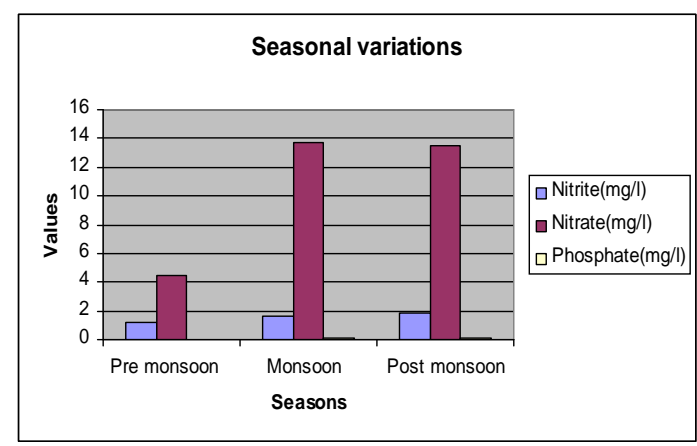

Figure 8. Seasonal variations in Nitrite, Nitrate and Phosphate.

Nutrients are considered as one of the most important parameters in the aquatic environment influencing growth, 
reproduction and metabolic activities of living being. Distribution of nutrients is mainly based on the season, tidal conditions and freshwater flow from land source. High concentration of inorganic phosphates $(0.10375 \pm 0.049423 \mathrm{mg} / \mathrm{l})$ observed during monsoon season might possibly be due to intrusion of upwelling seawater into the creek, which increased the level of phosphate (Nair et al., 1984) The recorded low phosphates value during dry seasons could be attributed to the limited flow of freshwater, high salinity and utilization of phosphate by phytoplankton (Senthilkumar et al., 2002; Rajasegar, 2003). The addition of super phosphates applied in the agricultural fields as fertilizers and alkyl phosphates used in households as detergents can be other sources of inorganic phosphates during the season (Tiwari and Nair, 1993).

\section{Acknowledgements}

The author (R.Surana) is thankful to UGC for providing Junior Research Fellowship. The author is grateful to Dr. A.G Thivakaran, Senior Scientist, Gujarat institute of Desert Ecology for his immense help and encouragement in carrying out the research and preparation of the paper.

\section{References}

Ajithkumar, T.T., T. Thangaradjou and L. Kannan 2006. Physico-chemical and biological properties of the Muthupettai mangrove in Tamil Nadu. $J$. Mar. Biol. Ass. India, 48: 131-138.

APHA 1998, Standard Methods for Examination of Water and Wastewater. 20 th Edn. American Public Health Association, Washington, DC, New York

Asha, P.S. and R. Diwakar 2007. Hydrobiology of the inshore waters off Tuticorin in the Gulf. J. Mar. Biol. Ass. India 49: 7-11.
Ashok Prabu, V., M. Rajkumar and P. Perumal 2008.Seasonal variations in Physico-chemical characteristics of Pichavaram mangroves, southeast coast of India. J. Environ. Biol.29: 945950.

Ayati, B., 2003. Investigation of sanitary and industrial wastewater effects on Anzali Reserved Wetland (Final report). MAB-UNESCO, Tarbiat Modarres University, Iran, 53p.

Balasubramanian, R. and L. Kannan 2005.Physicochemical characteristics of the coral reef Environs of the Gulf of Mannar Biosphere Reserve, India. Int. J. Ecol. Environ. Sci., 31: 265-271.

Bardarudeen, T., K.T. Damodaran, K. Sajan and D. Padmalal.1996.Texture and geochemistry of the sediments of a tropical mangrove ecosystem, southwest coast of India. Environ. Geol. 27:164169.

Clark, R.B. 1986. Marine pollution. $3^{\text {rd }}$ ed Oxford Science Press Publication, Calendon. B, pp. 433443.

Das, J., S.N. Das and R.K. Sahoo 1997. Semidiurnal variation of some physicochemical parameters in the Mahanadi estuary, east coast of India. Ind. $J$. Mar. Sci.26: 323-326.

Gibson, R. N.1982. Recent studies on the biology of intertidal fishes. Oceanogr. Mar. Biol. Ann. Rev.20: 363-414.

Govindasamy, C., L. Kannan and Jayapaul Azariah 2000. Seasonal variation in Physico- chemical properties and primary production in the coastal water biotopes of Coromandel coast, India. $J$. Environ. Biol.21:1-7.

Gowda, G., K.M. Rajesh and R.M. Mridula 2009. Vertical distribution of polychaetes in brackishwater pond of Nethravathi estuary, India. J. Environ. Biol. 30:1025-1029.

Izonfuo W. A and. L Bariweni 2001.The effect of urban runoff water and human activies on some physicochemical parameters of the Epie creek in the Niger Delta. J. Appl. Sci. \& Enviro. Mgt, 5(1): 4755.

Joseph K. 0, and J. P. Srivastava 1993. Heavy Metal Load in Edible Oyster, Crassoskrea madrasensis (Fres ton) from the Ennore Estuary in Madras, $J$. Environ. Biol. 14(2):121-127

Karuppasamy, P.K. and P. Perumal 2000. Biodiversity of zooplankton at Pichavaram mangroves, South India. Ad. Biosci.19: 23-32. 
Kasturirangan, L.R. 1963. Key to the identification of the common pelagic copepods of Indian coastal waters. Publication No 2. CSLS. Publication. p. 87

Kataria, H.C., H.A. Quereshi, S.A. Iqbal and A.K. Shandilya 1996, Assessment of water quality of Kolar Reservoir in Bhopal (MP). Pollution Research 15: 191-193.

Kawabata, Z., A. Magendran, S. Palanichamy V.K. Venugopalan and R. Tatsukawa 1993. Phytoplankton biomass and productivity of different size fractions in the Vellar estuarine system, southeast coast of India. Indian J. Mar. Sci.22: 294- 296.

Mani, P. and K. Krishnamurthy.1989. Variation of phytoplankton in a tropical estuary (Vellar estuary, Bay of Bengal, India) Int. Revue. Ges. Hydrobiol.74:109- 115.

Mitra, A., K.C. Patra and R.C. Panigrahy 1990. Seasonal variations of some hydrographical parameters in a tidal creek opening into the Bay of Bengal, Mahasagar. Bull. Natn. Inst. Oceanogr.23: 55-62.

Morris, A. W., Allen, J. I., Howland, R. J. M., and Wood, R.G. (1995). The estuary plume zone: source or sink for land derived nutrient discharges? Estuarine, Coastal and Shelf Science 40: 387-402.

Murugan, A. and K. Ayyakkannu 1991.Ecology of Uppanar backwater, Cuddalore. I. Physicochemical parameters. Mahasagar. Bull. Natl. Ins. Oceanogr. 24: 31-38.

Nair, P.V.R., C.P. Gopinathan, V.K. Balachandran, K.J. Mathew, A. Regunathan, D.S. Rao and A.V.S. Nixon and S. W. 1988. Physical energy inputs and the comparative ecology of lake and marine ecosystems. Limnol. Oceanogr. 33: 10051025.

Odokuma, L. O.and G. C. Okpokwasili.1997.Seasonal influences on the organic pollution monitoring of the New Calabar River, Nigeria. Environ. Monitor. Assess. 45(1):43-56.

Paramasivam, S. and L. Kannan 2005. Physicochemical characteristics of Muthupettai mangrove environment, Southeast coast of India. Int. J. Ecol. Environ. Sci., 31: 273-278.

Rajaram, R., M. Srinivasan and M. Rajasegar 2005. Seasonal distribution of physico- chemical parameters in effluent discharge area of Uppanar estuary, Cuddalore, South-east coast of India. $J$. Environ. Biol. 26:291-297.
Rajasegar, M., M. Srinivasan and S. Ajmal Khan. 2002. Distribution of sediment nutrients of Vellar estuary in relation to shrimp farming. Indian $J$. Marine Sci.31:153-156.

Rajasegar, M. 2003. Physico-chemical characteristics of the Vellar estuary in relation to shrimp farming. J. Environ. Biol. 24: 95-101.

Sai Sastry, A.G.R. and P. Chandramohan 1990. Physico-chemical characteristics of VasishtaGodavari estuary, eastcoast of India: Pre-pollution status. Indian J. Mar. Sci. 19: 42-46.

Sampathkumar, P. and L. Kannan 1998. Seasonal variations in physico-chemical characteristics in the Tranquebar -Nagapattinam region, southeast coast of India. Pollut. Res. 17: 397-402.

Santhanam, P. and P. Peruma 2003. Diversity of zooplankton in Parangipettai coastal waters, southeast coast of India. J. Mar. Biol. Ass. India 45:144-151.

Saravanakumar, A., M. Rajkumar, J. Sesh Serebiah and G.A. Thivakaran 2008. Seasonal variations in physico-chemical characteristics of water, sediment and soil texture in arid zone mangroves of Kachchh-Gujarat. J. Environ. Biol.29: 725-732.

Satpathy,K.K. 1996. Seasonal distribution of nutrients in the coastal waters of Kalpakkam, East coast of India. Ind. J. Mar. Sci.25: 221-224.

Senthilkumar, S., P. Santhanam and P. Perumal 2002. Diversity of phytoplankton in Vellar estuary, southeast coast of India. In: Proc. 5th Indian Fisheries Forum (Eds. S. Ayyappan, J.K. Jena and M. Mohan Joseph). Published by AFSIB, Mangalore and AeA, Bhubanewar, India. pp. 245248

Swami, B.S., V.G. Suryavanshi and A.A. Karande 1996. Hydrographic and micronutrient profile of Karwar coastal waters, west coast of India. Ind. J. Mar. Sci. 25: 349-351.

Tiwari, L.R. and V.R. Nair 1993. Zooplankton composition in Dharamtar creek adjoining Bombay harbour. Indian J. Mar. Sci. 22: 63-69.

Trivedy, R.K. and P.K. Goel 1984. Chemical Biological Methods for Water Pollution Studies. Environmental Publication, Karad, India, p 104.

Vengadesh, P.N., M. Rajkumar, P. Perumal and K. Thillai Rajasekar 2009. Seasonal variations of plankton diversity in the Kaduviyar estuary, Nagapattinam, southeast coast of India. $J$. Environ. Biol.30: 1035-1046. 
M. Gadhia, R. Surana and E. Ansari / Our Nature (2012) 10: 249-257

Vijayakumar, S., K.M. Rajan, R. Mridula, Mendon and Hariharan 2000. Seasonal distribution and behavior of nutrients with reference to tidal rhythm in the Mulki estuary, southwest coast of India. J. Mar. Biol. Ass. India 42: 21-24.
Walkely, A. and I.A Black. 1934. An examination of the Degtjareff method for determining soil organic matter and a proposed modification of the chromic acid titration method. Soil sci.34:29-38. 